\section{Procesos de constitución \\ de los movimientos piqueteros \\ en la provincia de Neuquén}

José Luis Bonifacio; Enrique Mases;

Demetrio Taranda

Los autores son Profesores e Investigadores

de la Facultades de Humanidades y de Derecho

y Ciencias Sociales de la Universidad Nacional del

Comahue. Av. Argentina 1400, Neuquén,

E-mail: boniluis@ciudad.com.ar

\section{Resumen}

El trabajo analiza los movimientos sociales en la provincia de Neuquén, a partir de la protesta social inaugurada con la aparición de los piqueteros en la localidad de Cutral-Co en el año 1996.

Se presentan primero dos antecedentes históricos: la huelga petrolera del 58 y el choconazo, a los efectos de comparar las características de estos conflictos sociales con las formas que asume la protesta a partir de los años noventa. Posteriormente se analiza el antecedente más cercano a las puebladas de Cutral-Có: la conformación de la Coordinadora de Desocupados en al año 1995. Este intento frustrado de organización de los desocupados en Neuquén Capital, casi un año antes de la primer pueblada, constituye un anticipo de lo que posteriormente ocurriría en las ciudades petroleras. Finalmente se describen parte de los acontecimientos de la primer pueblada. En el análisis se enfatiza el entramado político caracterizado por el clientelismo y la lucha facciosa al interior del partido gobernante; elementos centrales que atraviesan las luchas sociales en la provincia.

En la segunda parte se enuncian los condicionantes generales que contribuyen a la constitución del entramado sociopolítico en el cual se desarrollan las luchas sociales. Se analizan las organizaciones piqueteras presentando a modo de avance una tipología de las mismas.

\section{Summary}

This research analyzes the social movements in Neuquén Province (Argentina), and it is grounded on the social protest of 1996 as a starting point of the Picketers'Movement in Cutral-Có (Neuquén).

In the first part of the article, two historical antecedents of the protest are taken into account: the "Petrol Workers Strike" in 1958 and the «Choconazo" (related to El Chocón, a location placed in Neuquén), in order to compare the characteristics of these social conflicts with the ones the protest assumes since the beginning of the 90's. After this, we analyze the closest antecedent of the Cutral-Có Popular Uprising: The "Un-employeds Coordination", set up in 1995. This aborted inten-tion of organization tried by the unemployeds of Neuquén City almost a year before the first popular uprising, constitu-tes an advance of the protests which were going to happen later in different petrol areas of the Province. Finally, part of the events of the first popular uprising are well described. Here, the clientelism and tendentious struggles found out at the inside of the Official Party in the Government are em-phasized, because of being considered relevant throughout all the social movements set up in Neuquén.

Subsequently, we point out the general facts that contribute to the socio-political net, where social protests are held. Here, picketers'organizations are analyzed and a typology of them is presented. 